\title{
VIII МІЖНАРОДНА НАУКОВО-ПРАКТИЧНА КОНФЕРЕНЦІЯ «ЄВРОПЕЙСЬКА ІНТЕГРАЦІЯ ВИЩОÏ ОСВІТИ УКРАÏНИ В КОНТЕКСТІ БОЛОНСЬКОГО ПРОЦЕСУ»
}

\author{
7 лисmonada 2019 р., м. Київ, Україна \\ https://doi.org/10.37472/2707-305X-2019-1-1-3-5
}

VIII Міжнародна науково-практична конференція «Європейська інтеграція вищої освіти України в контексті Болонського процесу» відбулася 7 листопада 2019 р. у Київському національному університеті імені Тараса Шевченка.

Організатори конференції - Міністерство освіти і науки України, Національна академія педагогічних наук України, Інститут вищої освіти НАПН України, Київський національний університет імені Тараса Шевченка, Спілка ректорів вищих навчальних закладів України, Національний Еразмус+ офіс в Україні, Національні експерти 3 реформування вищої освіти Програми Еразмус+, Британська Рада в Україні. Ї̈̈ ключовим акцентом цього року визначили пріоритет «студентоцентроване навчання, викладання та оцінювання як частина системи забезпечення якості вищої освіти».

Участь у конференції взяли 137 осіб представники організаторів, закладів вищої освіти України та країн Європейського Союзу, Міністерства освіти і науки України, Національного агентства забезпечення якості вищої освіти та ін.

З вітальним словом до учасників конференції звернулися:

- Володимир Бугров, проректор Київського національного університету імені Тараса Шевченка;

- Василь Кремень, президент Національної академії педагогічних наук України;

- Сергій Квіт, голова Національного агентства із забезпечення якості вищої освіти;

- Саймон Вільямс, директор Британської Ради в Україні;

- Світлана Шитікова, директор Національного Еразмус+ офісу в Україні.

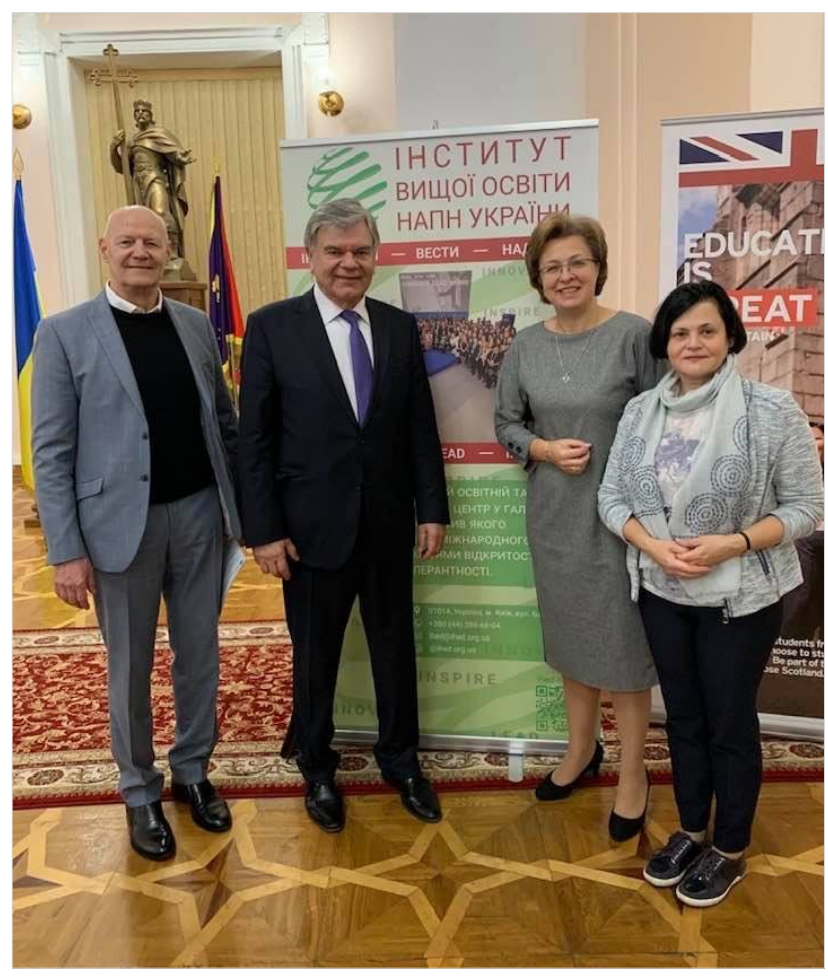

У межах Конференції свої експертні позиції представили:

- Олег Шаров, генеральний директор Директорату вищої освіти та освіти дорослих, член Національної команди експертів із реформування вищої освіти України - доповідь «Вища школа України: на старті турбореформ»;

- Амелія Веіга, доцент факультету психології та освітніх наук Університету Порту (Португалія) доповіді «Підходи Європейського простору вищої освіти до викладання і навчання у контексті забезпечення якості», «Визнання результатів навчання у рамках кредитної мобільності»;

- Сабіна Хойдн, керівник лабораторії студентоцентрованого навчання Школи гуманітарних та соціальних наук Інституту соціології Університету 
Св. Галлена (Швейцарія) - доповідь «Студентоцентроване навчання та викладання»;

- Юрій Рашкевич, Радник Міністра освіти і науки України, член Національної команди експертів із реформування вищої освіти України доповідь «Розроблення і затвердження, моніторинг та періодичний перегляд освітніх програм відповідно до студентоцентрованого викладання та навчання, НPК, стандартів, вікна мобільності».

У межах Конференції також був презентований досвід:

- університетів України щодо розбудови внутрішніх систем забезпечення якості (Київського університету імені Тараса Шевченка, Київського національного торгово-економічного університету, Харківського національного економічного університету імені Семена Кузнеця);

- Національного агентства забезпечення якості щодо розбудови національної системи акредитації освітніх програм;

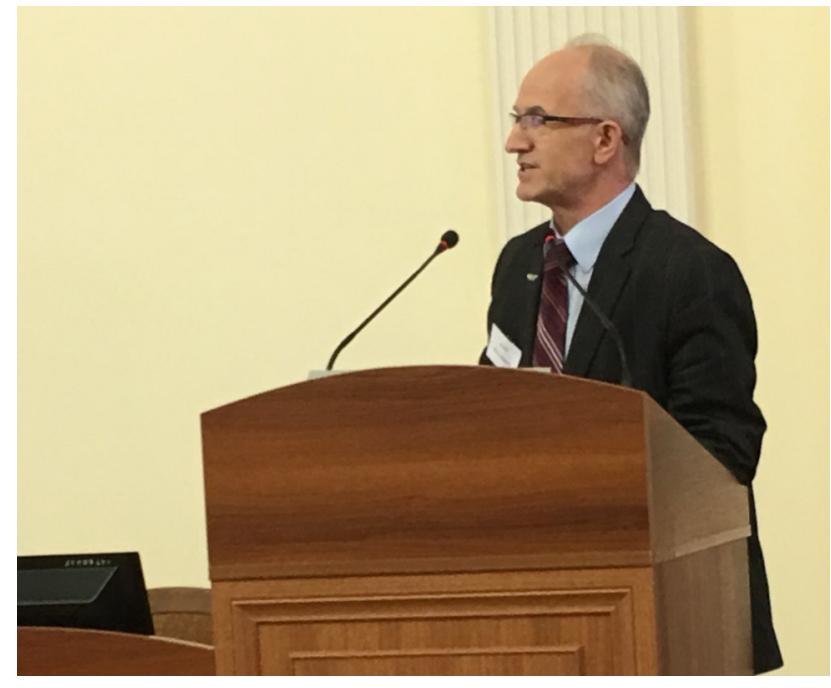

- Національного центру з покращення якості освіти Грузії щодо впливу системи забезпечення якості на вищу освіту.

Усі матеріали Конференції розміщені на вебсайті Інституту вищої освіти НАПН України за посиланням.

КАЛАШНІКОВА Світлана Андріївна доктор педагогічних наук, професор, член-кореспондент НАПН України, директор Інституту вищої освіти Національної академії педагогічних наук України, м. Київ, Україна

\section{8th INTERNATIONAL CONFERENCE "EUROPEAN INTEGRATION OF UKRAINE'S HIGHER EDUCATION IN THE CONTEXT OF BOLOGNA PROCESS" November 7, 2019, Kyiv, Ukraine}

\section{Svitlana Kalashnikova}

DSc in Education, Professor, Corresponding Member of NAES of Ukraine, Director, Institute of Higher Education of the National Academy of Educational Sciences of Ukraine, Kyiv, Ukraine

Abstract. The 8th international conference "European Integration of Ukraine's Higher Education in the Context of Bologna Process" was held November 7, 2019 in Taras Shevchenko National University of Kyiv.

The conference was organized by the Ministry of Education and Sciences of Ukraine, National Academy of Educational Sciences of Ukraine, Institute of Higher Education of NAES of Ukraine, Taras Shevchenko National University of Kyiv, Union of Rectors of Ukrainian Higher Education Institutions, National Erasmus+ office - Ukraine, National Teams of Higher Education Reform Experts, British Council Ukraine. Its main focus was "student-centered learning, teaching and evaluation as a part of quality assurance in higher education".

137 representatives of organizers, higher education institutions of Ukraine and the EU countries, Ministry of Education and Sciences of Ukraine, National Agency for Higher Education Quality Assurance (Ukraine), etc. participated within the conference.

Keywords: higher education; Bologna process; European Higher Education Area; international conference. 